Research Paper

\title{
Arbuscular mycorrhizal fungi in saline soils: Vertical distribution at different soil depth
}

\author{
Alejandra Becerra ${ }^{1}$, Norberto Bartoloni ${ }^{2}$, Noelia Cofré ${ }^{1}$, \\ Florencia Soteras ${ }^{1}$, Marta Cabello ${ }^{3}$ \\ ${ }^{1}$ Instituto Multidisciplinario de Biología Vegetal, Consejo Nacional de Investigaciones Científicas y \\ Técnicas, Facultad de Ciencias Exactas, Físicas y Naturales, Universidad Nacional de Córdoba, Córdoba, \\ República Argentina. \\ ${ }^{2}$ Facultad de Agronomía, Universidad de Buenos Aires, Buenos Aires, República Argentina. \\ ${ }^{3}$ Instituto Spegazzini, Facultad de Ciencias Naturales y Museo, Universidad Nacional de La Plata, \\ La Plata, República Argentina.
}

Submitted: March 7, 2013; Approved: March 14, 2014

\begin{abstract}
Arbuscular mycorrhizal fungi (AMF) colonize land plants in every ecosystem, even extreme conditions such as saline soils. In the present work we report for the first time the mycorrhizal status and the vertical fungal distribution of AMF spores present in the rhizospheric soil samples of four species of Chenopodiaceae (Allenrolfea patagonica, Atriplex argentina, Heterostachys ritteriana and Suaeda divaricata) at five different depths in two saline of central Argentina. Roots showed medium, low or no colonization (0-50\%). Nineteen morphologically distinctive AMF species were recovered. The number of AMF spores ranged between 3 and 1162 per $100 \mathrm{~g}$ dry soil, and AMF spore number decreased as depth increased at both sites. The highest spore number was recorded in the upper soil depth $(0-10 \mathrm{~cm})$ and in $S$. divaricata. Depending of the host plant, some AMF species sporulated mainly in the deep soil layers (Glomus magnicaule in Allenrolfea patagonica, Septoglomus aff. constrictum in Atriplex argentina), others mainly in the top layers (G. brohultti in Atriplex argentina and Septoglomus aff. constrictum in Allenrolfea patagonica). Although the low percentages of colonization or lack of it, our results show a moderate diversity of AMF associated to the species of Chenopodiaceae investigated in this study. The taxonomical diversity reveals that AMF are adapted to extreme environmental conditions from saline soils of central Argentina.
\end{abstract}

Key words: arbuscular mycorrhiza, saline environments, soil profile, vertical distribution, mycorrhizal status.

\section{Introduction}

In central Argentina 9\% of the area is occupied by halophytic vegetation (Cabido and Zak, 1999). This type of vegetation grows in habitats that are rare worldwide, since only approximately $7 \%$ of the global land surface is covered with saline habitats (Ruíz-Lozano and Azcón, 2000). Central Argentina presents some conspicuous salt flats: the Salinas Grandes and the Salinas de Ambargasta, which together occupies an area of approximately 600,000 hectares. The environmental isolation, the harsh climatic conditions, the characteristics of marginal lands for agriculture and livestock and no stable human population within it, have facilitated the preservation of this pristine ecosystem. Within these saline habitats, the distribution patterns of plant communities are defined by the salt gradient, with plant cover inversely proportional to the presence of salt. At sites where plant life is still possible, the most characteristic plant community is the halophytic shrub or jumeal, composed of species of the Chenopodiaceae family (Cabido and Zak, 1999).

Send correspondence to A. Becerra. Instituto Multidisciplinario de Biología Vegetal, Consejo Nacional de Investigaciones Científicas y Técnicas, Facultad de Ciencias Exactas, Físicas y Naturales, Universidad Nacional de Córdoba, C.C. 495. 5000 Córdoba, República Argentina. E-mail: abecerra@com.uncor.edu. 
According to Juniper and Abbott (1993), high salinity in soils has adverse effects on plant colonization by arbuscular mycorrhizal fungi (AMF). However, there are reports in the literature from all over the world that plants of salt marshes can be colonized by AMF (Hildebrandt et al., 2001; Juniper and Abbott, 1993; Landwehr et al., 2002; Smith and Read, 2008; Wang et al., 2004). Even in families that are generally considered non-mycorrhizal, such as Chenopodiaceae (Gerdemann, 1968; Hirrel et al., 1978; Mohankumar and Mahadevan, 1987; Peterson et al., 1985), the most salt-tolerant Salicornia sp. and Suaeda maritima can be colonized (Kim and Weber, 1985; Rozema et al., 1986; Sengupta and Chaudhuri, 1990).

Ecological studies on the community structure of AMF are generally restricted to the top $20 \mathrm{~cm}$ of soil, where most of the root biomass is concentrated (Brundrett, 1991). Only a few studies included the subsoil. Mycorrhizal colonization (Jakobsen and Nielsen, 1983; Rillig and Field, 2003), infective propagules (Ann et al., 1990), extra-radical mycelium (Kabir et al., 1998) and AMF spores (Oehl et al., 2005) decrease with increasing soil depth. Few studies have documented what happens with AMF diversity along soil profile. Cooke et al. (1993), Oehl et al. (2005), Cuenca and Lovera (2010) and Wang et al. (2004) have published the species diversity and distribution across the soil profile in salt marsh grasses in the United States, in cultivated soils of Central Europe, tropical soils of Venezuela and in the Yellow River Delta of China, respectively. Until now, nothing has been reported about vertical distribution of AMF communities in natural saline soils of Central Argentina.

In the present work we report for the first time the mycorrhizal status and the vertical fungal spores in four species of Chenopodiaceae (Allenrolfea patagonica (Moq.) Kuntze, Atriplex argentina Speg., Heterostachys ritteriana (Moq.) Moq. and Suaeda divaricata Moq.) in two saline soil of central Argentina. Species of Chenopodiaceae are the only plants able to growth in such extremophilus conditions and in Argentina ecosystems have not been previously examined for AMF presence.

\section{Materials and Methods}

\section{Study area and sample collection}

The study was conducted in two saline "Salinas de Ambargasta" -SA- $\left(64^{\circ} 18^{\prime} \mathrm{W}, 29^{\circ} 27^{\prime} \mathrm{S}\right)$ and "Salinas Grandes" -SG- (64\%31' W, 2944' S), in the north of Córdoba Province, central Argentina. The climate in both sites is dry and warm, with a mean annual precipitation below $500 \mathrm{~mm}$ and mean temperature of $19.9^{\circ} \mathrm{C}$. The highest areas (170 masl, with low salt concentration) are occupied by a xerophytic forest of Aspidosperma quebracho-blanco Schltdl., Prosopis flexuosa DC., Cercidium australe Johnst., Mimozyganthus carinatus (Grisseb.) Bukart, Ziziphus mistol Griseb., Prosopis torquata (Cav. ex Lag.) DC., and Stetsonia coryne (Salm-Dyck) Britton \& Rose; the understory vegetation is represented by Larrea divaricata $\mathrm{Cav}$. and some halophytes.

Our studied area, the edge of the salt flat, shows heavy constraints to the developing of any type of plant cover, being extremely open and scarce with the only presence of four species adapted to harsh environment: Allenrolfea patagonica (Moq.) Kuntze, Atriplex argentina Speg., Heterostachys ritteriana (Moq.) Moq. and Suaeda divaricata Moq. (Cabido and Zak, 1999; Cabido et al., 2006). Sampling was made in an area of approximately $50 \mathrm{x}$ $50 \mathrm{~m}$ in the two sites in end of the growing season (March, Summer) because during this period the plants present their full splendor (with flowers). Soil samples were randomly and carefully taken with a metal corer ( $3 \mathrm{~cm}$ of diameter) from under the canopy of five plants of each species to confirm connection between roots and shoots. The five soil samples per species were considered replicates.

Samples were collected from 0 to more than $40 \mathrm{~cm}$ in depth, at 10-cm intervals (at 0-10, 10-20, 20-30, 30-40, and $40-50 \mathrm{~cm}$ depths) in each site. Samples from each layer $\left(620 \mathrm{~cm}^{3}\right.$ soil volume) of each replicate were placed in individual plastic bags and stored at $4{ }^{\circ} \mathrm{C}$.

To characterize the soil from each site, four soil samples per depth level were taken and the following parameters were measured: electrical conductivity $(\mathrm{mmhos} / \mathrm{cm})$, extractable $\mathrm{P}$ determined with the method of Bray and Kurtz I (Jackson, 1964), $\mathrm{pH}$ in water (1:2.5), organic matter content (Nelson and Sommers, 1982), carbon: nitrogen ratio and soil texture. Total nitrogen was determined using the micro-Kjeldhal method (Bremner and Mulvaney, 1982).

\section{AMF colonization and spores}

Fresh roots were rinsed with water, cleared with $10 \%$ $\mathrm{KOH}\left(15\right.$ min at $\left.90{ }^{\circ} \mathrm{C}\right)$ and bleached with $30 \% \mathrm{H}_{2} \mathrm{O}_{2}$ (10 min, room temperature), acidified with $1 \% \mathrm{HCl}(1 \mathrm{~min}$, room temperature) and stained for $5 \mathrm{~min}$ in $0.05 \%$ trypan blue (Phillips and Hayman, 1970). To confirm mycorrhizal structure, in a second stage we then mounted the roots on glass slides for examination under a Kyowa 4-100x microscopic. The presence of arbuscules, vesicles, hyphal coils and intra- and intercellular hyphae without septa were used to designate AM associations. Quantification of AM root colonization was estimated visually as the proportion of the root which was colonized and characterized using five classes: very high $(>80 \%)$, high $(60-79 \%)$, medium (40$59 \%)$, low (20-39\%), and very low (1-19\%), following Zangaro et al. (2002).

AMF spores were extracted from $100 \mathrm{~g}$ (dry weight) of each soil sample by wet sieving and decanting (Gerdemann and Nicolson, 1963), and the supernatant was centrifuged in a sucrose gradient (Walker et al., 1982). The procedure included passage through $500-, 125-$, and $38-\mu \mathrm{m}$ sieves. The $500-\mu \mathrm{m}$ sieve was checked for large spores, spore clusters, and sporocarps. The contents of the 125- and 
38- $\mu \mathrm{m}$ sieves were layered onto a water-sucrose solution (70\% [wt/vol]) gradient and centrifuged at $900 \times \mathrm{x}$ for 2 min. Only apparently healthy spores (those that contained cytoplasm, with no collapsed surface and no evidence of parasitism) were counted under stereomicroscope directly.

For taxonomic identification, fungal spores and sporocarps were mounted onto slides using PVA (polyvinyl alcohol) with and without Melzer reagent (Omar et al., 1979) and examined with a compound microscope. AMF species were identified following original species descriptions and those presented by INVAM (International Culture Collection of Arbuscular and Vesicular-Arbuscular Mycorrhizal Fungi), Szcezecin University and Redecker et al. (2013). Vouchers were deposited in the Herbarium at the Spegazzini Institute (LPS), La Plata, Argentina.

Spore number and AMF species richness in different soil layers were expressed as follows: total number of spores and number of AMF species in $100 \mathrm{~g}$ dry soil. Soil moisture content was calculated for each soil sample as percent oven-dry weight of soil by drying at $80^{\circ} \mathrm{C}$ for $48 \mathrm{~h}$.

Species diversity was measured by the Shannon diversity index, which combines two components of diversity, species richness and evenness. It is calculated with the equation

$$
H=\sum_{i=1}^{s} p_{i}\left(\log _{2} p_{i}\right)
$$

where $p_{i}$ is the probability of finding each species $i$ in one sample.

\section{Statistical analysis}

To evaluate the effect of depth level (within-subjects variables), sites and hosts species (between-subjects factors) on spore number, richness and diversity of AMF a repeated measures analysis of variance (ANOVA) followed by a Bonferroni multiple comparisons with a significance level of 0.05 was performed. All residuals were tested for normality and homocedasticity with Shapiro-Wilks and Levenes tests, respectively. AMF spore number was log transformed. All statistics were performed using STATISTICA program of statsoft (http://www.statsoft.com/) Version 8.

\section{Results}

Soils of Salinas de Ambargasta (SA) and Salinas Grandes (SG) were Aridisol-Orthid typic Salorthids (INTA, 2003). Both sites presented a sandy clay loam texture, high $\mathrm{pH}$ and electrical conductivity, and slightly CEC and organic matter content. Depth level influenced significantly some soil parameters (Table 1). A decrease in organic matter content, $\mathrm{C}, \mathrm{N}, \mathrm{K}$ and an increase in $\mathrm{Na}$ with increasing soil depth were observed (Table 1).

Roots from $A$. patagonica, $A$. argentina, $H$. ritteriana and $S$. divaricata were colonized and showed entry points, intraradical aseptate hyphae, intracellular hyphal coils and intracellular vesicles in both sites at all soil depths. Arbuscules were not detected. AM colonization in plant species was very low to low (5-31\% and 2-37\%) in $A$. patagonica and $S$. divaricata, respectively; in H. ritteriana and $A$. argentina AM colonization was very low to medium (0-45\% and 4-50\%), respectively.

A total of 19 morphologically distinctive AMF species were recovered, and 14 could be attributed to known species belonging to eigth genera (Acaulospora, Ambispora, Claroideoglomus, Diversispora, Glomus, Funneliformis, Rhizophagus and Septoglomus) (Table 2). The community of spores was dominated by Glomus brohultti, Septoglomus aff. constrictum and Funneliformis geosporum. In total four morphotypes belonging to Glomus were found (two glomoid morphotypes remain unidentified, Figure 1). Five morphotypes belongs to Acaulospora (two acaulosporoid morphotypes remain unidentified, Figure 1), three to Claroideoglomus, two to Funneliformis and Rhizophagus, one to Ambispora, Diversispora and Septoglomus.

Brief morphological characteristics of two glomoid and acaulosporoid unknown morphotypes are described below.

Glomoid morphotype sp. 1: Spores reddish brown; globlose to subglobose, $72-130 \mu \mathrm{m} \times 82-130 \mu \mathrm{m}$. Subtending hyphae: straight to curved; wall continuous with spore wall and slightly lighter in color than spore wall. Pore closure: septum under spore base. Other characteristics: irregular globular projections (3-5) x (5-6) $\mu \mathrm{m}$ slightly lighter in color than spore wall (Figure $1 \mathrm{a}-\mathrm{b}$ ).

Glomoid morphotype sp. 2: Spores orange; globose to subglobose, 60-112 $\mu \mathrm{m} \times$ 60-112 $\mu \mathrm{m}$. Subtending hyphae: straight; wall continuous with spore wall and slightly lighter in color than spore wall. Pore closure: constricted at spore base. Other characteristics: irregular globular projections slightly lighter in color than spore wall. Usually, very long subtending hyphae (Figure $1 \mathrm{c}-\mathrm{d}$ ).

Acaulosporoid morphotype sp. 1: Spores hyaline to orange, globose to subglobose, 75-150 $\mu \mathrm{m} \times$ 60-180 $\mu \mathrm{m}$. Spore wall with three layers. The outer hyaline, thin and flexible. Middle layer pale yellow, very fine, with numerous folds on the spore surface and appears "rugose". The third layer is a thin layer, less than $1 \mu \mathrm{m}$ thick. It often is adherent to the spore wall in which case it cannot be detected (Figure 1 e).

Acaulosporoid morphotype sp. 2: Spores orange to red orange, globose to subglobose, 50-90 $\mu \mathrm{m} \times 45-80 \mu \mathrm{m}$. The outer layer continuous with the wall of the sporiferous saccule. Spore wall with three layers, the outer layer degrading and sloughing. Middle layer orange, with circular to ovoid depressions (Figure $1 \mathrm{f}$ ). The third layer shows a positive Melzers reaction. 
Table 1 - Soil properties of the two study sites, Salinas de Ambargasta (SA) and Salinas Grandes (SG), at five depth levels (0-10, 10-20, 20-30, 30-40, and $40-50 \mathrm{~cm}){ }^{\text {a }}$ : Mean value of 4 samples. Values within a row followed by the same letter were not significantly different for each saline site among soil depth $(\mathrm{p}<0.05){ }^{\mathrm{b}}$ : OM: organic matter content, $\mathrm{C}$ : carbon, $\mathrm{N}$ : total nitrogen; $\mathrm{C} / \mathrm{N}$ : carbon/nitrogen ratio, $\mathrm{P}$ : available phosphorus, EC: electrical conductivity, Ca: calcium, Mg: magnesium, K: potassium, Na: sodium, CEC: cation exchange capacity.

\begin{tabular}{|c|c|c|c|c|c|c|}
\hline Parameters & & $0-10 \mathrm{~cm}^{\mathrm{a}}$ & $10-20 \mathrm{~cm}$ & $20-30 \mathrm{~cm}$ & $30-40 \mathrm{~cm}$ & $40-50 \mathrm{~cm}$ \\
\hline \multirow[t]{2}{*}{$\mathrm{OM}(\%)^{\mathrm{b}}$} & SA & $1.29 \pm 0.40 \mathrm{a}$ & $0.81 \pm 0.18 \mathrm{ab}$ & $0.82 \pm 0.17 \mathrm{ab}$ & $0.71 \pm 0.21 \mathrm{~b}$ & $0.65 \pm 0.23 \mathrm{~b}$ \\
\hline & SG & $2.30 \pm 1.93 \mathrm{a}$ & $1.41 \pm 1.06 \mathrm{a}$ & $1.04 \pm 0.61 \mathrm{a}$ & $1.05 \pm 0.71 \mathrm{a}$ & $0.86 \pm 0.46 \mathrm{a}$ \\
\hline \multirow[t]{2}{*}{$\mathrm{C}(\%)$} & SA & $0.64 \pm 0.20 \mathrm{a}$ & $0.41 \pm 0.09 a b$ & $0.41 \pm 0.13 \mathrm{ab}$ & $0.36 \pm 0.11 \mathrm{~b}$ & $0.33 \pm 0.11 b$ \\
\hline & SG & $1.15 \pm 0.97 \mathrm{a}$ & $0.71 \pm 0.53 \mathrm{a}$ & $0.52 \pm 0.31 \mathrm{a}$ & $0.53 \pm 0.36 \mathrm{a}$ & $0.43 \pm 0.23 \mathrm{a}$ \\
\hline \multirow[t]{2}{*}{ N (\%) } & SA & $0.08 \pm 0.03 \mathrm{a}$ & $0.05 \pm 0.02 \mathrm{ab}$ & $0.04 \pm 0.02 b c$ & $0.04 \pm 0.01 b c$ & $0.03 \pm 0.01 \mathrm{c}$ \\
\hline & SG & $0.11 \pm 0.07 \mathrm{a}$ & $0.08 \pm 0.06 \mathrm{a}$ & $0.06 \pm 0.04 \mathrm{a}$ & $0.04 \pm 0.02 \mathrm{a}$ & $0.04 \pm 0.02 \mathrm{a}$ \\
\hline \multirow[t]{2}{*}{$\mathrm{C} / \mathrm{N}$} & SA & $8.24 \pm 1.72 \mathrm{a}$ & $7.90 \pm 0.62 \mathrm{a}$ & $10.26 \pm 2.57 \mathrm{ab}$ & $10.47 \pm 2.88 \mathrm{ab}$ & $12.93 \pm 2.59 \mathrm{~b}$ \\
\hline & SG & $9.79 \pm 2.35 \mathrm{a}$ & $9.23 \pm 2.48 \mathrm{a}$ & $10.91 \pm 3.63 \mathrm{a}$ & $11.95 \pm 2.04 \mathrm{a}$ & $12.52 \pm 0.65 \mathrm{a}$ \\
\hline \multirow[t]{2}{*}{$\mathrm{P}(\mathrm{ppm})$} & SA & $11.61 \pm 6.74 \mathrm{a}$ & $10.89 \pm 7.93 \mathrm{a}$ & $8.53 \pm 5.55 \mathrm{a}$ & $8.76 \pm 5.65 \mathrm{a}$ & $9.17 \pm 4.81 \mathrm{a}$ \\
\hline & SG & $7.04 \pm 3.39 \mathrm{a}$ & $6.48 \pm 2.68 \mathrm{a}$ & $6.60 \pm 3.40 \mathrm{a}$ & $7.17 \pm 4.15 \mathrm{a}$ & $9.93 \pm 4.40 \mathrm{a}$ \\
\hline \multirow[t]{2}{*}{$\mathrm{pH} 1: 2.5$} & SA & $8.17 \pm 0.57 \mathrm{a}$ & $8.11 \pm 0.50 \mathrm{a}$ & $8.07 \pm 0.42 \mathrm{a}$ & $8.02 \pm 0.37 \mathrm{a}$ & $8.17 \pm 0.50 \mathrm{a}$ \\
\hline & SG & $7.76 \pm 0.16 \mathrm{a}$ & $7.89 \pm 0.19 \mathrm{a}$ & $7.84 \pm 0.10 \mathrm{a}$ & $7.89 \pm 0.19 \mathrm{a}$ & $7.82 \pm 0.09 \mathrm{a}$ \\
\hline \multirow[t]{2}{*}{$\mathrm{EC}\left(\mathrm{dS} \cdot \mathrm{m}^{-1}\right)$} & SA & $11.45 \pm 5.79 \mathrm{a}$ & $13.53 \pm 4.53 \mathrm{a}$ & $17.19 \pm 5.12 \mathrm{a}$ & $17.58 \pm 3.90 \mathrm{a}$ & $18.85 \pm 4.86 \mathrm{a}$ \\
\hline & SG & $9.35 \pm 5.56 \mathrm{a}$ & $12.48 \pm 6.05 \mathrm{a}$ & $14.36 \pm 4.04 \mathrm{a}$ & $11.98 \pm 5.48 \mathrm{a}$ & $14.91 \pm 3.42 \mathrm{a}$ \\
\hline \multirow[t]{2}{*}{$\mathrm{Ca}(\mathrm{Cmolc} / \mathrm{kg})$} & SA & $8.44 \pm 4.94 \mathrm{a}$ & $8.21 \pm 5.09 \mathrm{a}$ & $8.64 \pm 5.20 \mathrm{a}$ & $8.98 \pm 5.17 \mathrm{a}$ & $10.03 \pm 5.98 \mathrm{a}$ \\
\hline & SG & $8.94 \pm 2.20 \mathrm{a}$ & $9.46 \pm 2.73 \mathrm{a}$ & $9.85 \pm 2.15 \mathrm{a}$ & $10.51 \pm 1.51 \mathrm{a}$ & $11.11 \pm 2.34 \mathrm{a}$ \\
\hline \multirow[t]{2}{*}{$\mathrm{Mg}(\mathrm{Cmolc} / \mathrm{kg})$} & SA & $1.19 \pm 0.67 \mathrm{a}$ & $1.11 \pm 0.62 \mathrm{a}$ & $1.13 \pm 0.64 \mathrm{a}$ & $1.14 \pm 0.64 \mathrm{a}$ & $1.19 \pm 0.67 \mathrm{a}$ \\
\hline & SG & $1.46 \pm 0.07 \mathrm{a}$ & $1.39 \pm 0.02 \mathrm{a}$ & $1.50 \pm 0.07 \mathrm{a}$ & $1.45 \pm 0.12 \mathrm{a}$ & $1.44 \pm 0.12 \mathrm{a}$ \\
\hline \multirow[t]{2}{*}{$\mathrm{K}(\mathrm{Cmolc} / \mathrm{kg})$} & SA & $0.56 \pm 0.31 \mathrm{a}$ & $0.45 \pm 0.26 \mathrm{a}$ & $0.38 \pm 0.22 \mathrm{a}$ & $0.37 \pm 0.21 \mathrm{a}$ & $0.37 \pm 0.23 \mathrm{a}$ \\
\hline & SG & $0.82 \pm 0.10 \mathrm{a}$ & $0.64 \pm 0.14 \mathrm{ab}$ & $0.54 \pm 0.03 b c$ & $0.44 \pm 0.07 \mathrm{c}$ & $0.43 \pm 0.14 \mathrm{c}$ \\
\hline \multirow[t]{2}{*}{$\mathrm{Na}(\mathrm{Cmolc} / \mathrm{kg})$} & SA & $1.07 \pm 0.58 \mathrm{a}$ & $1.12 \pm 0.62 \mathrm{a}$ & $1.20 \pm 0.67 \mathrm{a}$ & $1.22 \pm 0.69 \mathrm{a}$ & $1.20 \pm 0.70 \mathrm{a}$ \\
\hline & SG & $1.25 \pm 0.13 \mathrm{ab}$ & $1.21 \pm 0.12 \mathrm{a}$ & $1.39 \pm 0.17 \mathrm{ab}$ & $1.55 \pm 0.23 \mathrm{~b}$ & $1.56 \pm 0.30 \mathrm{ab}$ \\
\hline \multirow[t]{2}{*}{$\mathrm{CEC}(\mathrm{Cmolc} / \mathrm{kg})$} & SA & $14.41 \pm 2.23 \mathrm{a}$ & $13.50 \pm 2.06 \mathrm{a}$ & $13.04 \pm 2.57 \mathrm{a}$ & $14.10 \pm 1.46 \mathrm{a}$ & $13.44 \pm 6.11 \mathrm{a}$ \\
\hline & SG & $11.31 \pm 2.69 \mathrm{a}$ & $12.26 \pm 3.07 \mathrm{a}$ & $12.48 \pm 2.70 \mathrm{a}$ & $13.32 \pm 2.36 \mathrm{a}$ & $13.59 \pm 2.61 \mathrm{a}$ \\
\hline
\end{tabular}

Table 2 lists the relative abundance of all AMF species collected ordered according to soil profile, sites and plant species. Clearly the majorities of AMF spore types were rare and apparently did not change along soil profile. The majority of AMF occurred in low densities (relative abundance $<1 \%$ ). Depending on the plant species, some species were increasingly found with increasing soil depth, at least in relative terms. These were Glomus magnicaule in Allenrolfea patagonica and Septoglomus aff. constrictum in Atriplex argentina. Some species sporulated in the top layers; these were G. brohultti in Atriplex argentina and Septoglomus aff. constrictum in Allenrolfea patagonica.

The AMF spores number ranged between 3 and 1162 per $100 \mathrm{~g}$ dry soil (mean number:166 \pm 75 ). Spore number varied from 7 to 591 per $100 \mathrm{~g}$ dry soil in Salinas de Ambargasta (mean number: $122 \pm 37$ ) and from 3 to 1162 per $100 \mathrm{~g}$ dry soil in Salinas Grandes (mean number: $210 \pm$
117). Spores number was high in the upper soil horizon $(0-10 \mathrm{~cm})$, decreasing with increasing soil depth. AMF spores differed among plant species throughout soil depths (Table 3). Significant differences were observed among rhizospheres of the different plant species and soil depths, and among sites and soil depths. A significant triple interaction among soil depth $\mathrm{x}$ plant species $\mathrm{x}$ site was observed, indicating that AMF spore number decreases as depth increases at both sites (Figure 2).

AMF species diversity and richness differed significantly among rhizospheres of the host species and sites (Tables 3, 4). Similarly to observed for spore number, a significant triple interaction among soil depth $\mathrm{x}$ host plant species $\mathrm{x}$ site were evidenced in AMF species diversity and richness, indicating that all ecological parameters decrease in plant species as depth increases at both sites. The highest value of species diversity and richness was recorded in $S$. divaricata $(\mathrm{H}=2.3$, richness 8 species $)$. 


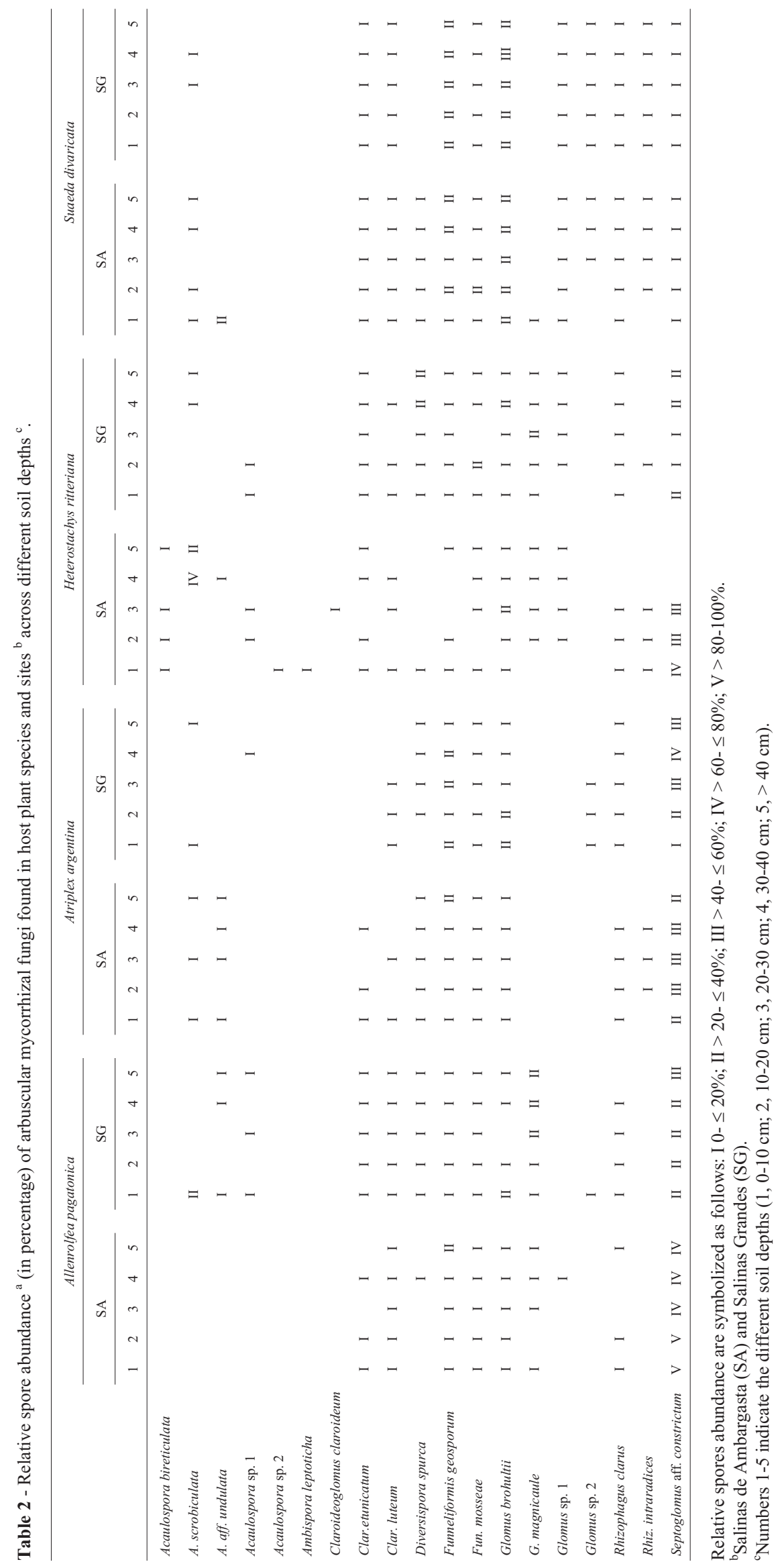



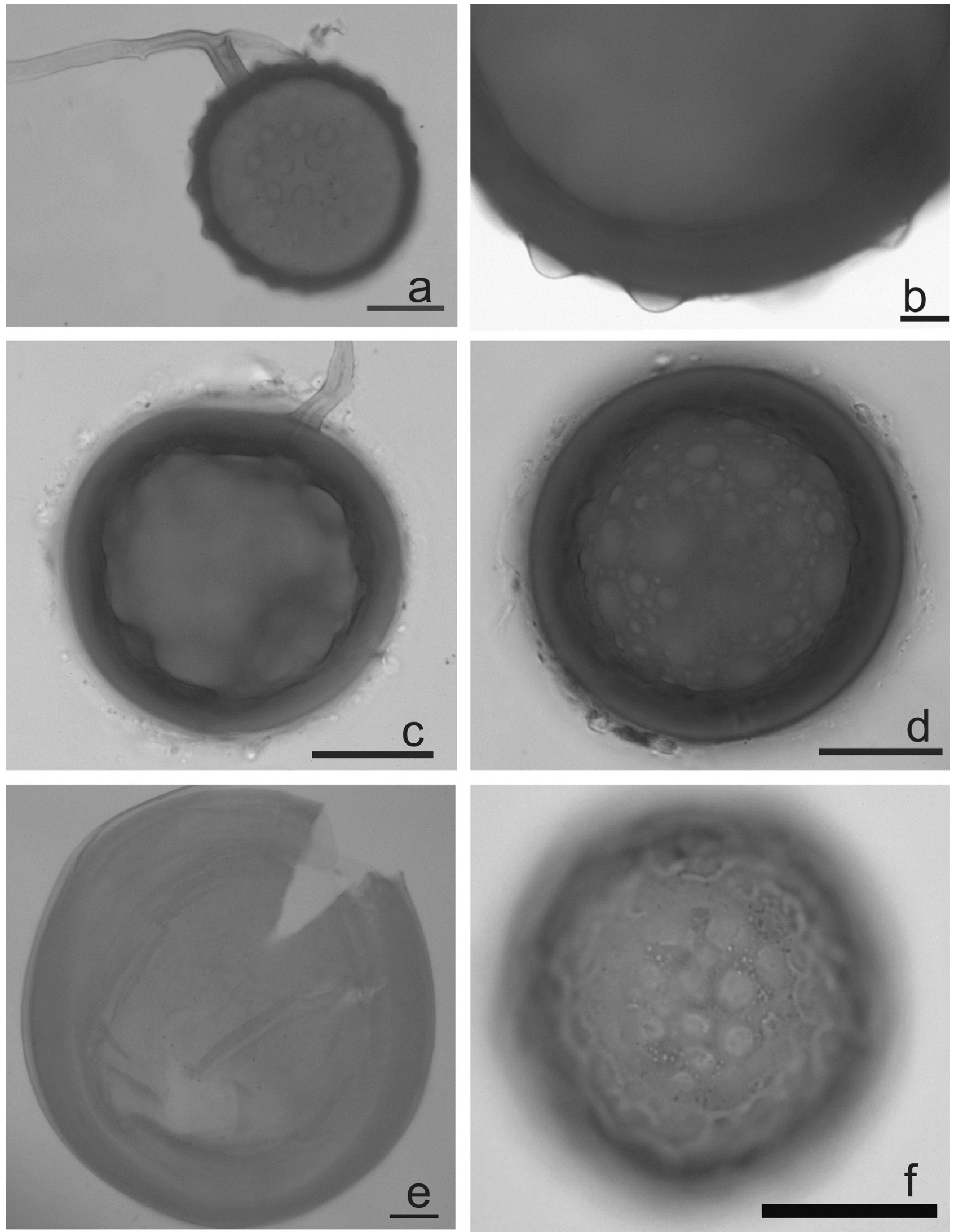

Figure 1 - Arbuscular mycorrhizal fungi found in Chenopodiaceae species from saline soils of Central Argentina. a-b: Glomoid morphotype sp. 1. c-d: Glomoid morphotype sp. 2 e: Acaulosporoid morphotype sp. 1. f: Acaulosporoid morphotype sp. 2. Scale bar a, c, d, e, f: $50 \mu \mathrm{m} ; \mathrm{b}: 10 \mu \mathrm{m}$. 

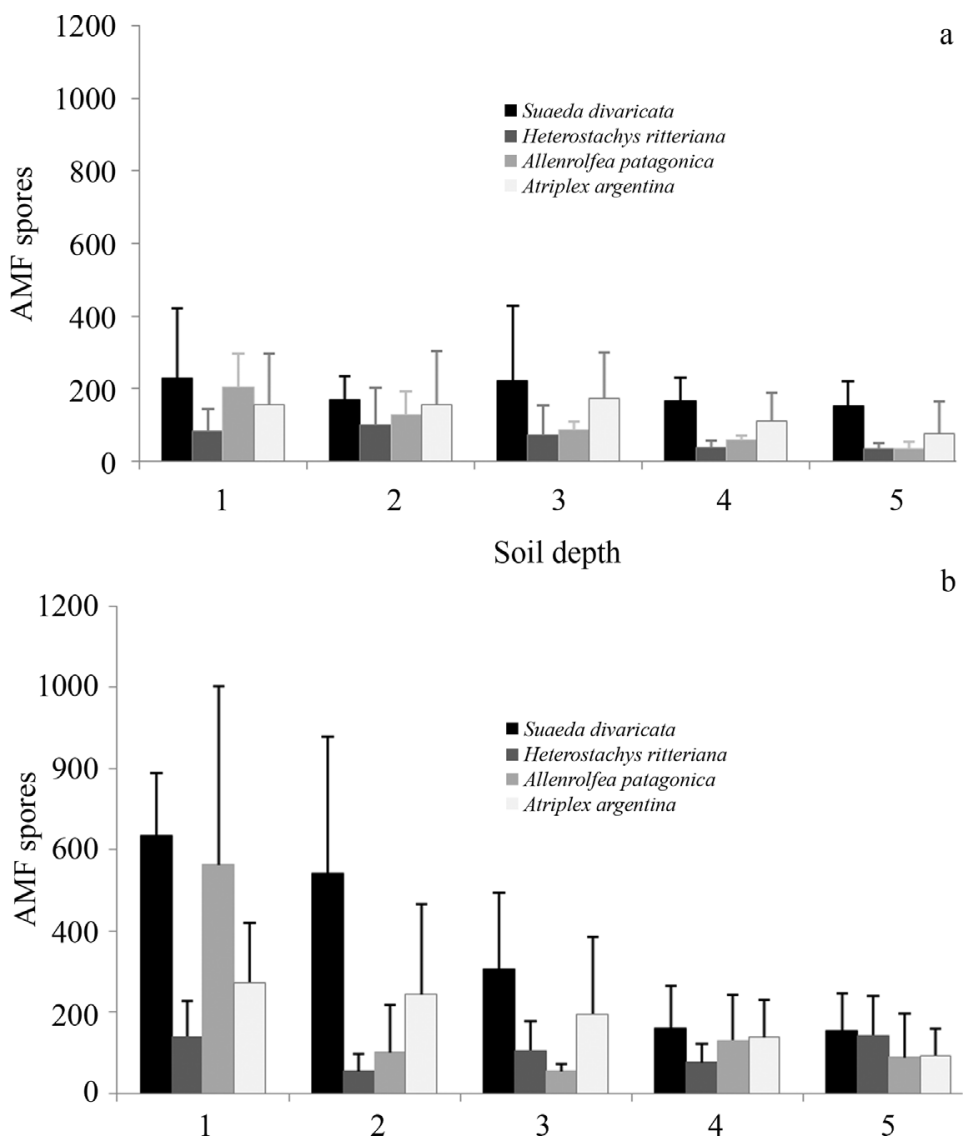

Figure 2 - Spore density of AMF (100 g dry soil) in four host plant species at different soil depths in both sites (a: Salinas de Ambargasta (SA), b: Salinas Grandes (SG)). Host plant species: Suaeda divaricata, Heterostachys ritteriana, Allenrolfea patagonica and Atriplex argentina. Soil depths 1 (0-10 cm), $2(10-20 \mathrm{~cm}), 3(20-30 \mathrm{~cm}), 4(30-40 \mathrm{~cm}), 5(>40 \mathrm{~cm})$; errors bars represent standard errors.

Table 3 - $F$-values from repeated measured ANOVA for Arbuscular Mycorrhizal Spores (AMS), Arbuscular Mycorrhizal Diversity (AMD) and Arbuscular Mycorrhizal Richness (AMR) in Host Plant Species (HPS), sites (S) (Salinas de Ambargasta and Salinas Grandes) and soil depth (SD).

\begin{tabular}{lccc}
\hline & AMS & AMD & AMR \\
\hline Within-subject effects & & & \\
Soil depth (SD) & $17.407^{* * *}$ & 1.7680 & 1.8760 \\
SD x HPS & $2.456^{* *}$ & $2.3100^{*}$ & $3.0614^{* *}$ \\
SD x S & $2.460^{*}$ & $12.6139^{* * *}$ & $7.7972^{* * *}$ \\
SD x HPS x S & $2.265^{*}$ & $5.3024^{* * *}$ & $5.7144^{* * *}$ \\
Between-subject effects & & & \\
Host plant species (HPS) & $5.150^{* *}$ & $16.5204^{* * *}$ & $16.5962^{* * *}$ \\
Sites (S) & 1.434 & $5.7848^{*}$ & $4.2074 *$ \\
HPS x S & 0.136 & 1.5919 & 0.3309 \\
\hline
\end{tabular}

* Significant at the level 0.05 .* Significant at the 0.01 level. *** Significant at the 0.001 level.

\section{Discussion}

Mycorrhizal symbiosis is a key component in helping plants cope with adverse environmental conditions (RuízLozano and Azcón, 2000). In this study, AMF was found to
Table 4 - Biodiversity index and species richness values for AMF morphotypes found in Salinas de Ambargasta and Salinas Grandes and hosts species. Data are means of one hundred replicates for each site and fifty replicates for each host. Values within a column followed by the same letter were not significantly different for sites $(p<0.05)$ for host species $(\mathrm{p}<0.0001)$.

\begin{tabular}{lcc}
\hline & Biodiversity index $(\mathrm{H})$ & Richness $(\mathrm{S})$ \\
\hline Salinas de Ambargasta & $1.72 \mathrm{~b}$ & $5.47 \mathrm{~b}$ \\
Salinas Grandes & $1.93 \mathrm{a}$ & $6.21 \mathrm{a}$ \\
Allenrolfea pagatonica & $1.5 \mathrm{c}$ & $5.04 \mathrm{a}$ \\
Atriplex argentina & $1.87 \mathrm{~b}$ & $5.24 \mathrm{a}$ \\
Heterostachys ritteriana & $1.62 \mathrm{bc}$ & $5.04 \mathrm{a}$ \\
Suaeda divaricata & $2.30 \mathrm{a}$ & $8.04 \mathrm{~b}$ \\
\hline
\end{tabular}

occur naturally in Chenopodiaceae plants across the soil profile in saline environments of Central Argentina.

The present study shows that the four species of Chenopodiaceae presented AM fungal structures in their roots. This finding is partly in agreement with the literature (Allen, 1983; Fontenla et al., 2001; Plenchette and Duponnois, 2005), especially under drought and salt-stress conditions (Sengupta and Chaudhuri, 1990). AM colonization of the plants sampled in this study was significantly higher than values reported by Wang et al. (2004), but similar to 
those of other plants species evaluated in saline soils (Hildebrandt et al., 2001; Landwehr et al., 2002).

The AMF diversity found in this study was higher than at two saline habitats in Netherlands and Northern Germany, where Wilde et al. (2009) found 14, 11 and 10 AMF species under Aster tripolium, Puccinellia distans and Salicornia europaea, respectively. In particular Funneliformis geosporum and F. mosseae has been widely reported for natural saline soils (Aliasgharzadeh et al., 2001; Carvalho et al., 2001; Hildebrandt et al., 2001; Wilde et al., 2009). Moreover, Claroideoglomus etunicatus was also found in saline soils of the Tabriz Plain of Iran (Aliasgharzadeh et al., 2001) and Ambispora leptoticha in saline-alkaline soils of the Yellow River Delta of China (Wang et al., 2004). As far as we know the other AMF species revealed here were not yet reported for saline soils.

AMF spore number in the rhizosphere of Chenopodiaceae plants, in deep soils, were similar to numbers in other saline soils (Aliasgharzadeh et al., 2001; García and Mendoza, 2008; Hildebrandt et al., 2001; Landwehr et al., 2002). This suggests that AMF distribution is related to the physiological characteristics of the host and morphology and distribution of roots (Ingleby et al., 1997; Wang et al., 2004). Most spores were found in the surface soil layer $(0-10 \mathrm{~cm})$, decreasing in number with increasing soil depth. Spore production is concentrated near the soil surface (Abbott and Robson, 1991; Cuenca and Lovera, 2010; Ingleby et al., 1997; Lovera and Cuenca, 2007; Oehl et al., 2005) and could be associated with the greater presence of fine roots than in the deeper soil layers. Although Pearson's correlations between these variables have not been significant, we observed that root density was highest in the top soil and decreased with increasing depth (data not shown). AMF are fully dependent on host carbon; hence, the distribution of AMF spores associated with the fine root distribution across the soil profile was not surprising.

In the complex saline environments where soil physical and chemical properties, plant ecophysiological adaptation, and temperature-moisture characteristics are closely related, soil nutrient sources will certainly facilitate soil biota coexistence and activity (Barness et al., 2009). The soils from central Argentina here analyzed were similarly to semi-arid and arid environments, where Chenopodiaceae are common (Aguilera et al., 1998; Aliasgharzadeh et al., 2001; Landwehr et al., 2002; Wilde et al., 2009). As increasing soil depth, differences in soil parameters (a reduction of $\mathrm{OM}, \mathrm{C}$ and $\mathrm{N}$ in $\mathrm{SA}$; a reduction of $\mathrm{K}$ and an increase of $\mathrm{Na}$ in $\mathrm{SG}$ ) were found. These soil differences probably affect AMF spore number, as was observed in other Chenopodiaceae species (Aguilera et al., 1998) and in other plant species (Verma et al., 2010).

High levels of AMF diversity were observed in the saline environments of central Argentina. Diversity values recorded in the present study are similar to those found in saline-alkaline soils of the Yellow River Delta (Wang et al.,
2004). The AMF species richness differed among the host species investigated across the soil profile. The same effect was reported by Oehl et al. (2005) across soil profile in intensively cultivated soils in Central Europe. The highest number of species and the highest diversity was found in Suaeda divaricata in the first two soil depths $(0-10,10-20)$. As Bellgard (1993) and Lovera and Cuenca (2007) stated, AMF spores are concentrated in the first centimeters of soil and decrease significantly in the deepest layers of the soil profile.

The AMF community composition changed along soil depth. The community seemed to be dominated by Glomus brohultti, Septoglomus aff. constrictum and Funneliformis geosporum. Depending of the host plant, some species sporulated mainly, or exclusively, in the deeper soil layers (Glomus magnicaule in Allenrolfea patagonica, Septoglomus aff. constrictum in Atriplex argentina), others mainly in the top layers ( $G$. brohultti in Atriplex argentina and Septoglomus aff. constrictum in Allenrolfea patagonica). As stated by Abe and Katsuya (1995), Ho (1987) and Wang et al. (2004). Glomeraceae species are the most commonly observed in stressful habitats.

AMF were described to protect plants against salinity (Ruíz-Lozano and Azcón, 2000) and AMF may have developed adaptive strategies to tolerate this stressful environment. In these saline environments, the interaction between host plant species and abiotic factors is so complex that AMF patterns are difficult to explain. The present study contributes to the knowledge of the vertical AMF distribution in extremely saline soils of two salines of Central Argentina and shows the high diversity of AMF in natural saline ecosystems. In addition, the results of our study demonstrate that these AMF species, belonging to different genera and families of Glomeromycota, are adapted to extreme environmental conditions and indicate the importance of conducting more exhaustive samplings (at different depths across the soil profile) to obtain a complete picture of AMF in the field.

\section{Acknowledgments}

This work was financially supported by Secretaría de Ciencia y Técnica - Universidad Nacional de Córdoba, Agencia de Promoción Científica y Tecnológica (PICT 438-2006) and Project, CICPBA for soil analysis. A.G.B. is researcher of the Consejo Nacional de Investigaciones Científicas y Tecnológicas (CONICET). M.C. is researcher from Comisión de Investigaciones Científicas de la provincia de Buenos Aires (CICPBA).

\section{References}

Abbott LK, Robson AD (1991) Factors influencing the occurrence of vesicular arbuscular mycorrhizas. Agric Ecosys Environ 35:121-150. 
Abe JP, Katsuya K (1995) Vesicular-arbuscular mycorrhizal fungi in coastal dune plant communities II. Spore formation of Glomus spp. Predominates under geographically separated patches of Elymus mollis. Mycoscience 36:113-116.

Aguilera LE, Gutierrez JR, Moreno RJ (1998) Vesicular arbuscular mycorrhizae associated with saltbushes Atriplex spp. (Chenopodiaceae) in the Chilean Arid Zone. Rev Chil Hist Nat 71:291-302.

Aliasgharzadeh N, Saleh Rastin N, Towfighi H, Alizadeh A (2001) Occurrence of vesicular arbuscular mycorrhizal fungi in saline soils of the Tabriz Plain of Iran in relation to some physical and chemical properties of soil. Mycorrhiza 11:119-122.

Allen MF (1983) Formation of vesicular-arbuscular mycorrhizae in Atriplex gardneri (Chenopodiaceae): seasonal response in a cold desert. Mycologia 75:773-776.

An ZQ, Grove JH, Hendrix JW, Hershman DE, Henson GT (1990) Vertical distribution of endogonaceous mycorrhizal fungi associated with soybean, as affected by soil fumigation. Soil Biol Biochem 22:715-719.

Barness G, Rodriguez Zaragoza S, Shmueli I, Steinberger Y (2009) Vertical distribution of a soil microbial community as affected by plant ecophysiological adaptation in a desert system. Microb Ecol 57:36-49.

Bellgard SE (1993) The topsoil as the major store of propagules of vesicular-arbuscular mycorrhizal fungi in southeast Australian sandstone soils. Mycorrhiza 3:19-24.

Bremner JM, Mulvaney CS (1982) Chemical and microbiological properties. In: Page, A.L. (ed). Methods of soil analysis. Part II. American Society of Agronomy: Soil Science Society of America, Madison, Wisconsin, pp 595-624.

Brundrett M (1991) Mycorrhizas in natural ecosystems. Adv Ecol Res 21:171-262.

Cabido M, Zak M (1999). Vegetación del Norte de Córdoba, Córdoba, Argentina.

Cabido M, Rosacher C, Roqué Garzón JM, Cabido D, Gorgas J, Piana J (2006) Reserva de Usos Múltiples Salinas Grandes. In: Cabido, M., Rosacher, C., Roqué Garzón, J.M., Cabido, D. (eds). Áreas Naturales Protegidas de la Provincia de Córdoba, Córdoba, Argentina, pp 81-96.

Carvalho LM, Caçador I, Martins-Loução MA (2001) Temporal and spatial variation of arbuscular mycorrhizas in salt marsh plants of the Tagus estuary (Portugal). Mycorrhiza 11:303309.

Cooke JC, Butler RH, Madole G (1993) Some observations on the vertical distribution of vesicular-arbuscular mycorrhizae in roots of salt marsh grasses growing in saturated soils. Mycologia 85:547-550.

Cuenca G, Lovera M (2010) Seasonal variation and distribution at different soil depths of arbuscular mycorrhizal fungi spores in a tropical sclerophyllous shrubland. Botany 88:54-64.

Fontela S, Chaia E, Bustos C, Pelliza A (2001) Microorganismos simbióticos en Atriplex. XXVIII Jornadas Argentinas de Botánica, La Pampa, Argentina. Bol Soc Arg Bot 36:114.

García I, Mendoza R (2008) Relationships among soil properties, plant nutrition and arbuscular mycorrhizal fungi plant symbioses in a temperate grassland along hydrologic, saline and sodic gradients. FEMS Microbiol Ecol 63:359-371.

Gerdemann JW (1968) Vesicular arbuscular mycorrhiza and plant growth. Ann Rev Phytopatol 6:397-418.
Gerdemann JW, Nicolson TH (1963) Spores of a mycorrhizal Endogone species extracted from the soil by wet sieving and decanting. Trans Brit Mycol Soc 46:235-244.

Hildebrandt U, Janetta K, Fouad O, Renne B, Nawrath K, Bothe H (2001) Arbuscular mycorrhizal colonization of halophytes in Central European salt marshes. Mycorrhiza 10:175-183.

Hirrel MC, Mehravaran H, Gerdemann JW (1978) Vesiculararbuscular mycorrhizae in the Chenopodiaceae and Cruciferae: do they occur? Can J Bot 56:2813-2817.

Ho I (1987) Vesicular-arbuscular mycorrhizae of halophytic grasses in the Alvard desert of Oregon. Northwest Sci 61:148151.

Ingleby K, Diagne O, Deans JD, Lindley DK, Neyra M, Ducousso M (1997) Distribution of roots, arbuscular mycorrhizal colonisation and spores around fast-growing tree species in Senegal. For Ecol Manag 90:19-27.

INTA (Instituto Nacional de Tecnología Agropecuaria) (2003) Recursos Naturales de La Provincia de Córdoba: Los Suelos, Nivel de Reconocimiento 1:500.000, Argentina.

INVAM (International Culture Collection of Arbuscular and Vesicular-Arbuscular Mycorrhizal Fungi) http://invam.caf.wvu.edu/Myc_Info/Taxonomy/species.htm.

Jackobsen I, Nielsen NE (1983) Vesicular-arbuscular mycorrhiza in field-grown crops I. Mycorrhizal infection in cereals and peas at various times and soil depths. New Phytol 93:401413.

Jackson ML (1964) Análisis Químico de Suelos. Omega, Barcelona.

Juniper S, Abbott L (1993) Vesicular-arbuscular mycorrhizas and soil salinity. Mycorrhiza 4:45-57.

Kabir Z, O’Halloran IP, Widden P, Hamel E (1998) Vertical distribution of arbuscular mycorrhizal fungi under corn (Zea mays L.) in no-till and conventional tillage systems. Mycorrhiza 8:53-55.

Kim C-K, Weber DJ (1985) Distribution of VA mycorrhiza on halophytes on inland salt playas. Plant Soil 83:207-214.

Landwehr M, Hildebrandt U, Wilde P, Nawrath K, Toth T, Biro B, Bothe H (2002) The arbuscular mycorrhizal fungus Glomus geosporum in European saline, sodic and gypsum soils. Mycorrhiza 12:199-211.

Lovera M, Cuenca G (2007) Diversidad de hongos micorrícicos arbusculares HMA y potencial micorrízico del suelo de una sabana natural y una sabana perturbada de la Gran Sabana Venezuela. Interciencia 322:1-8.

Mohankumar V, Mahadevan A (1987) Vesicular-arbuscular mycorrhizal association in plants of Kalakad reserve forest, India. Angew Bot 61:255-274.

Nelson DW, Sommers LE (1982) Total carbon, organic carbon, and organic matter. In: Page, A.L. (ed). Methods of soil analysis. Part II. American Society of Agronomy: Soil Science Society of America, Madison, Wisconsin, pp 539-579.

Oehl F, Sieverding E, Ineichen K, Ris EA, Boller T, Wiemken A (2005) Community structure of arbuscular mycorrhizal fungi at different soil depths in extensively and intensively managed agroecosystems. New Phytol 165:273-283.

Omar MB, Bolland L, Heather WA (1979) P.V.A. (polivinil alcohol). A permanent mounting medium for fungi. Bull Brit Mycol Soc 13:31-32. 
Peterson RL, Ashford AE, Allaway WG (1985) Vesicular-arbuscular mycorrhizal association of vascular plants on Heron Island, a great barrier reef coral ray. Aust J Bot 33:669-676.

Phillips JM, Hayman DS (1970) Improved procedures for clearing roots and staining parasitic and vesicular-arbuscular mycorrhizal fungi for rapid assessment of infection. Trans Brit Mycol Soc 55:158-161.

Plenchette C, Duponnois R (2005) Growth response of the saltbush Atriplex nummularia L. to inoculation with the arbuscular mycorrhizal fungus Glomus intraradices. J Arid Environ 61:535-540.

Redecker D, Schüßler A, Stockinger H, Stürmer SL, Morton JB, Walker C (2013) An evidence-based consensus for the classification of arbuscular mycorrhizal fungi (Glomeromycota). Mycorrhiza 23:515-531.

Rillig MC, Field CB (2003) Arbuscular mycorrhizae respond to plants exposed to elevated atmospheric $\mathrm{CO}_{2}$ as a function of soil depth. Plant Soil 254:383-391.

Rozema J, Arp W, van Diggelen J, van Esbroek M, Broekmann R, Punte H (1986) Occurrence and ecological significance of vesicular arbuscular mycorrhiza in the salt marsh environment. Acta Bot Neerlandica 35:457-467.

Ruíz-Lozano JM, Azcón R (2000) Symbiotic efficiency and infectivity of an autochthonous arbuscular mycorrhizal Glomus sp. from saline soils and $G$. deserticola under salinity. Mycorrhiza 10:137-143.

Sengupta A, Chaudhuri S (1990) Vesicular arbuscular mycorrhiza (VAM) in pioneer salt marsh plants of the Ganges River delta in West Bengal (India). Plant Soil 122:111-113.

Smith SE, Read DJ (2008) Mycorrhizal Symbiosis. 3er ed. Academic Press, Amsterdam, Boston.

Szczecin University Szcezecin University: http://agro.ar.szczecin.pl/ jblaszkowski/index.html

Walker C, Mize W, McNabb HS (1982) Populations of endogonaceous fungi at two populations in central Iowa. Can J Bot 60:2518-2529.

Wang FY, Liu RJ, Lin XG, Zhou JM (2004) Arbuscular mycorrhizal status of wild plants in saline-alkaline soils of the Yellow River Delta. Mycorrhiza 14:133-137.

Wilde P, Manal A, Stodden M, Sieverding E, Hildebrandt U, Bothe H (2009) Biodiversity of arbuscular mycorrhizal fungi in roots and soils of two salt marshes. Environ Microbiol 11:1548-1561.

Zangaro W, Nisizaki SMA, Domingos JCB, Nakano EM (2002) Arbuscular mycorrhizal in native woody species of Tibagi River Basin, Paraná. Cerne 8:77-87.

All the content of the journal, except where otherwise noted, is licensed under a Creative Commons License CC BY-NC. 